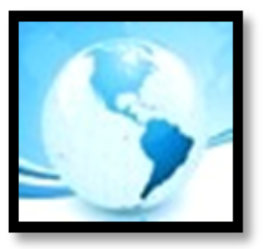

April 2018, VOLUME 6, ISSUE 2, 41 - 66

E-ISSN NO: $2289-4489$

https://doi.org/10.22452/mojem.vol6no2.3

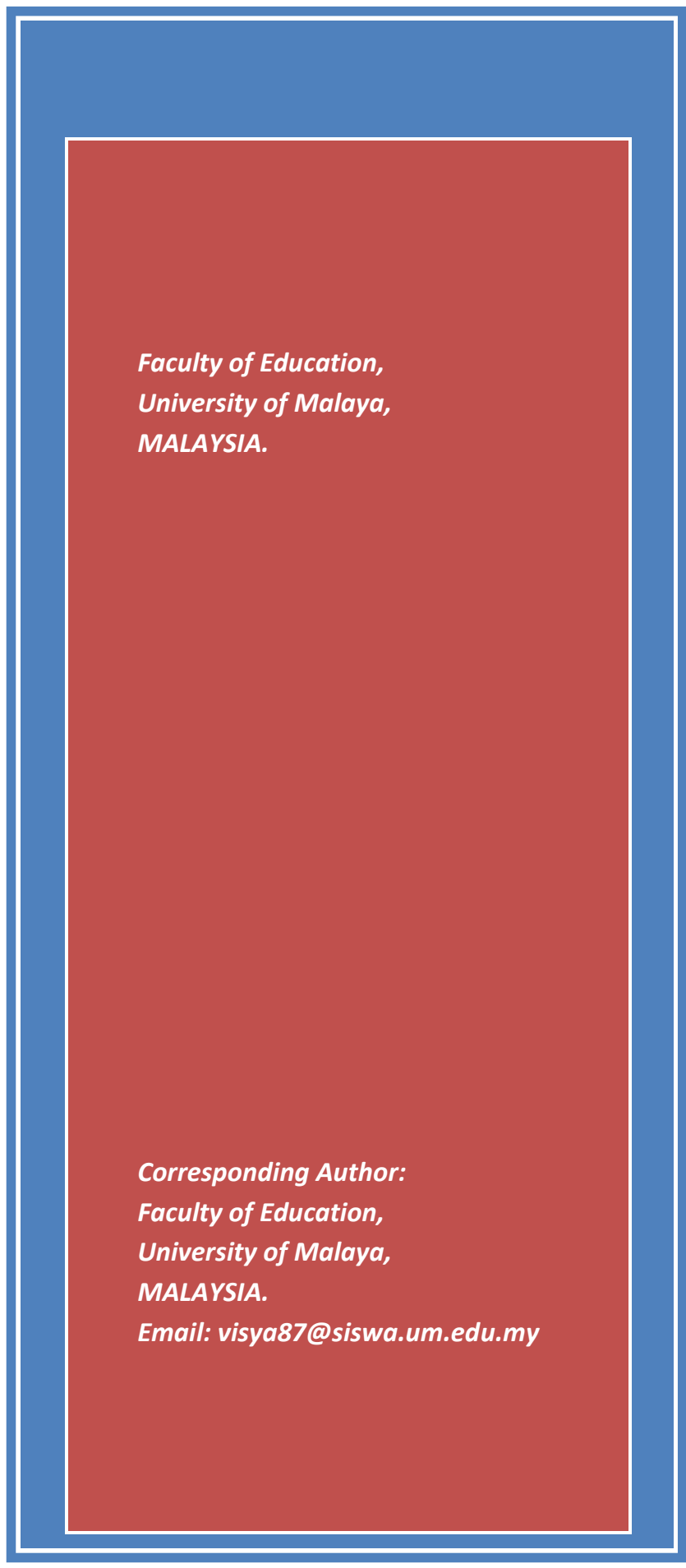

\section{FINANCIAL LITERACY EDUCATION AND RETIREMENT PLANNING IN MALAYSIA}

Visyalini Selvadurai, Husaina Banu Kenayathulla $(\mathrm{PhD})$ \& Saedah Siraj (PhD)

\begin{abstract}
Lack of education in financial literacy would lead to fallacious retirement planning decisions among elderly people. Many elderly people are facing dilemma of not having sufficient money to maintain their living upon retirement and this problem is becoming worse over time. Thus, this qualitative study explores the financial literacy education of elderly people and the influence on retirement planning in Malaysia. Data for probing the influence of financial literacy education on financial retirement planning of elderly people in Malaysia were collected using semi-structured interview questions and document analysis. Data were collected from 10 elderly people with financial education background and have experience in dealing with financial planning for retirement from Klang Valley, Malaysia. Purposeful sampling technique was used to collect data and thematic analysis was used to interpret the data collected in this study. The results of this study indicated that financial literacy education along with demographic factors and financial attitude factors play a crucial role in financial retirement planning before retirement. The results further indicate that psychological factors like monetary goal-setting, early financial exposure and financial awareness affect elderly people in enhancing financial literacy education, which eventually influence financial retirement planning. In order to improve on the financial planning for retirement, policy makers and government need to implement financial literacy education policy to aid elderly people in financial planning and retire with financial freedom.
\end{abstract}

Keywords: Financial Literacy, Elderly People, Retirement Planning, Education, Malaysia 


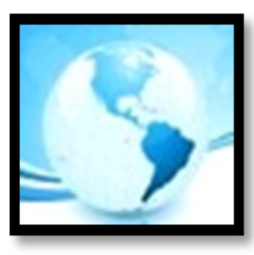

\section{INTRODUCTION}

Education affects nation development and economic growth (King, 2011). Education is an important factor in retirement planning. Financial knowledge enhances financial literacy education of individuals. In this current era with ultimate financial crisis, it is essential for each and every individual to equip himself or herself with pertinent financial knowledge. Those who are with good financial literacy education background are wiser in planning for their retirement (Klapper \& Panos, 2011).

Retirement is an essential life event which is experienced by every individuals and comfortable retirement requires a sensible planning. Individuals who do not give importance to retirement planning will not accumulate sufficient wealth for their retirement period in most of the countries including Malaysia (Ministry of Finance, Canada 2014; Nathan, 2015). Recently with the increasing number of elderly people, the issue of retirement planning will remain to be crucial and the financial retirement planning will be given importance by the governments from all over the world.

Financial literacy education has recently been highlighted as one of the contributing factor towards successful retirement planning. A number of policymakers and economists stated that financial literacy education is essential in ensuring financial comfort (Meier \& Sprenger, 2013).Can individuals effectively manage their financial well-being without proper guidance? Policy makers concluded that financial literacy education is a necessity solution to make financial decisions in the global monetary crisis period (Fernandes, Lynch \& Netemeyer, 2014).

Lack of financial literacy education would lead to fallacious retirement decisions among elderly people (Clark, 2012). It was found that many Americans are facing dilemma of not having sufficient money to maintain their living upon retirement and this problem is becoming worse over time (Miller, Madland \& Weller, 2015). In Malaysia, results of the Manulife Investor Sentiment Index (MISI) survey revealed that even though Malaysians' top priority is having savings for retirement, there is lack of financial planning among them as the current ratio of Malaysians' debt is $68 \%$ which is the highest ratio of all eight markets in Malaysia (Supriya, 2016).

Malaysians find that having sufficient savings upon retirement is a challenge (Suhaimi Abd Samad \& Norma Mansor, 2013). In Malaysia, both young and older individuals have lesser level of financial literacy education. They are not exposed much about the basic financial literacy education like concepts, with thoughtful effect of saving, retirement planning, mortgages, and other decisions (Krishna Moorthy et al., 2012).

The findings in this study can be helpful for other researchers to further investigate on how to expose the importance of financial literacy education to the elderly people to plan their retirement and retire with financial freedom. Policy makers can make an effort to look into the findings and if the findings are relevant to the elderly people in Malaysia and policy makers can develop relevant and helpful financial policies for elderly people. Many elderly people need to know what is the effect of financial literacy education on financial planning in order to make sound retirement decisions so that they can be financially independent even upon retirement and they can also have sufficient amount of bank balance as it will be useful for the especially when it comes to basic expenses like food, shelter, medical and etcetera.

Overall, this paper explores the influence of financial literacy education on financial retirement planning of the elderly people in Malaysia based from the perceptions of individuals with good financial literacy education background and have experience in planning for retirement. It could be beneficial for Malaysians to have a definite idea of the effect of financial literacy education on retirement planning. Therefore, the main objective of this study is to explore the financial literacy education of elderly people and the influence on financial retirement planning of elderly people in Malaysia. 


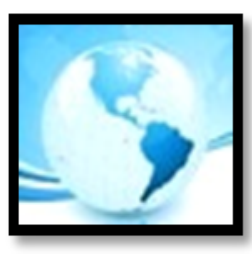

\section{THEORETICAL FOUNDATIONS}

The theories underlying this study are Life-Cycle Saving and Investing Theory and Theory of Mental Accounting. Life-Cycle Saving and Investing theory was developed by economists to guide individuals to make decisions in saving for retirement (Bodie, Treussard \& Willen, 2007). This theory helps in understanding how individuals make spending and saving decisions based on their life expectancy, income, retirement goals, and intergenerational transfer motives (Chaffin, 2013). This theory is the prominent theory as there is a need to have some literacy on finance for making proper decisions in financial planning in recent years as individuals are required to take greater responsibilities for their financial matters (Government of Canada, 2005).

Lusardi, Michaud and Mitchell (2013) developed an adjusted version of life cycle model by adding financial literacy as an endogenous variable and they found that investments in financial literacy can influence individuals' ability to save and invest for retirement well-being. Financial literacy strongly affects household wealth accumulation (Behrman, Mitchell, Soo \& Bravo, 2010).

One of the weaknesses of life-cycle and saving is that not all the individuals have broad financial literacy to make and execute complex plan to save sufficient money during their working period as studies show that individuals' saving manners are very different from the predictions of life-cycle savings theory (Bucher-Koenan, 2011; Lusardi \& Mitchell, 2013). For instance, current studies found that the rates of poverty in Organisation for Economic Cooperation and Development (OECD) countries are higher for elderly people (aged 65 or more) and in 27 out of 30 OECD countries, older women are at greater risk (OECD, 2011). These findings are contradictory with the Life Cycle Hypothesis. Older Americans, specifically women, minorities and those who are least educated are lack in financial literacy (Lusardi \& Mitchell, 2011). The conceptual framework of this study is designed based on this relevant theory in order to highlight the effect of financial literacy education on retirement planning as it emphasises on the importance of financial literacy education in making financial decisions.

In addition, the other theory which is closely related to financial literacy education and retirement planning is the theory of mental accounting. It is used in this study as it involves behaviouristic of individuals to plan their expenditure and save money for their future. This theory was developed by Thaler in year 1985 and he defined it as "The set of cognitive operations used by individuals and households to organize, evaluate, and keep track of financial activities" (Thaler, 1999, p.183). One of the strengths of this theory of mental accounting is, individuals do code and categorize all their expenditures in order to mentally divide the money that they have to make plans, keep track of their expenditure and avoid unnecessary overspending on products that are not useful (Cheema \& Soman, 2006; Thaler, 1999). This theory is used as the base for the conceptual framework of this study as it includes the financial attitude of individuals in managing money well. Individuals with financial literacy education will be aware of the basic monthly expenditure that they are committed to and have in their mental accounts is like electricity, water, telephone bills, credit cards, loans, rent and others. When individuals are committed to their expenditures, they can efficiently increase their savings (Kast, Meier \& Pomeranz, 2016).

One of the weaknesses of mental budgeting is that individuals tend to under consume for certain matter like entertainment and clothing (Heath \& Soll, 1996). In addition, individuals with an unstable household income would impose limits to their mental accounts as they face more difficulties in saving money compared to wealthier individuals (Salas, 2014). 


\section{CONCEPTUAL FRAMEWORK}

The research framework of this study was developed based on Theory of Life-Cycle Saving and Investing and Theory of Mental Accounting. Theory of Life-Cycle Saving and Investing which was developed by economists contributes in guiding individuals to make financial decisions in developing a better retirement planning. In addition, Theory of Mental Accounting includes the wise attitude of individuals to plan their future especially upon retirement. Overall, these two theories explained that individuals with proper financial literacy education tend to make pertinent decisions in their daily life and plan their retirement well.

The main reason for integrating these two theories is because the important elements of financial literacy education needed for financial planning were found in the theories but the influence of those elements on elderly people were not explored in Malaysia. Therefore, by combining the elements and exploring out the influence of financial literacy education on financial retirement planning, the end product would be beneficial for individuals who would want to plan their finance for retirement in future.

Thus, the conceptual framework of this study consists of four variables; demographic factors, financial literacy education factors, financial attitude factors and financial education factors. Demographic factors are analysed to learn more about a population. The findings for each population are different because the demographic factors vary accordingly. Demographic factors like age, education level, gender, and household income are considered important in studies related to retirement planning (Mohd Fitri Mansor, Chor, Noor Hidayah Abu \& Mohd Shahidan Shaari, 2015).

Additionally, individuals who equip themselves with financial literacy education, most likely would be wise enough to spend less amount than the income that they get and therefore they would have sufficient savings when their income fall especially upon retirement (Lusardi \& Mitchell, 2013). Furthermore, in determining financial literacy education of an individual, the attitude is considered as an essential component. Financial attitude include the beliefs and values of an individual on numerous personal finance concepts like whether the person believes it is essential to save money (Chowa, Despard \& Osei-Akoto, 2012). Positive and negative attitudes contribute towards the financial literacy of an individual.

Financial education increases financial literacy education of individuals. There is a strong relationship between financial education, financial literacy education and financial outcomes. Financial education aids in enhancing financial literacy education of individuals and they can also gain more confidence in making financial decisions (Brugiavini, Cavapozzi, Padula \& Pettinicchi, 2015). Figure 1 shows the conceptual framework for this study: 

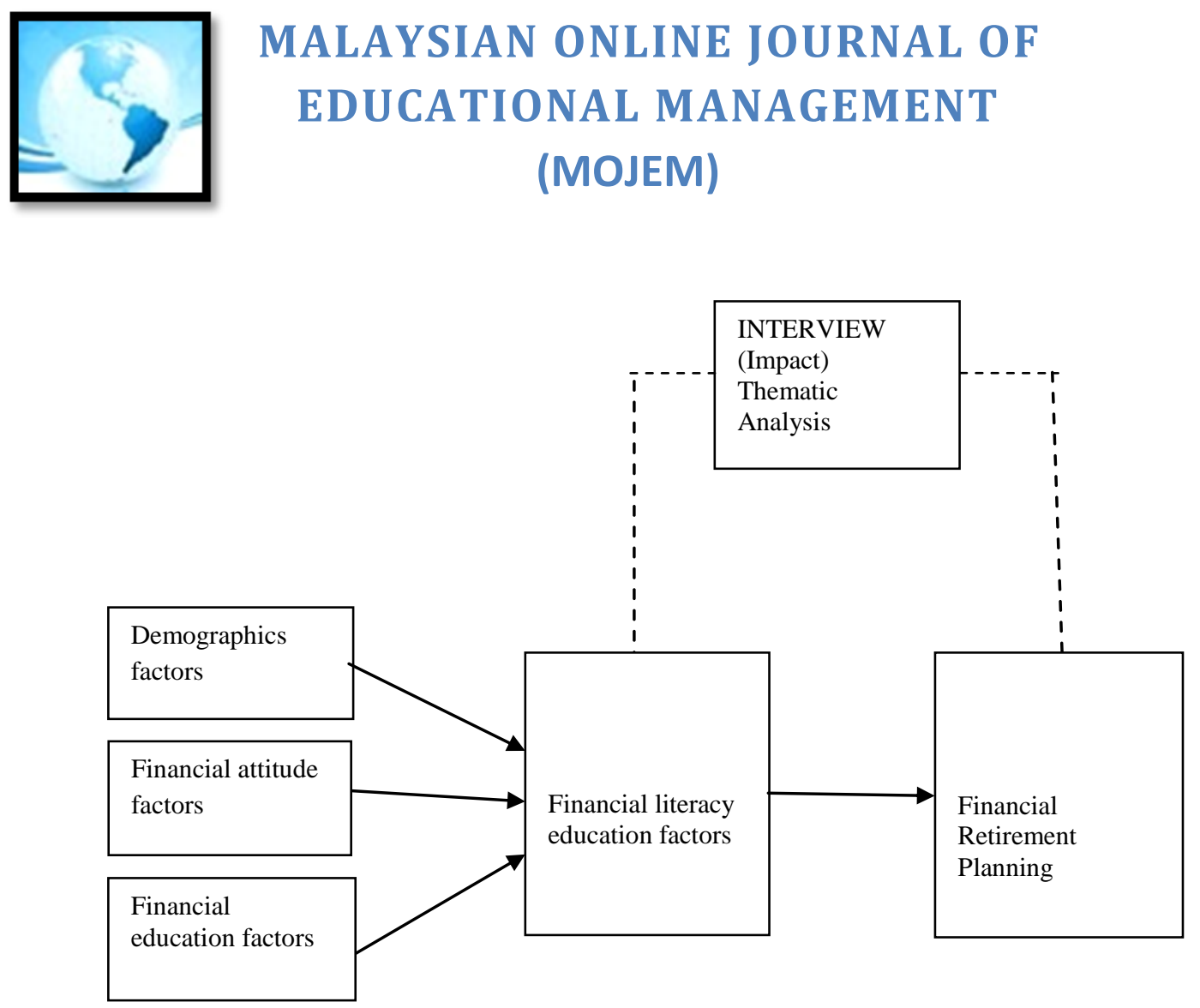

Figure 1. A Conceptual framework on financial literacy education and its outcome.

\section{LITERATURE REVIEW}

\section{Retirement Education}

Retirement is a period where an individual leaves the labour force after so many years of being in a committed job (Society of Actuaries Key Findings: Working in Retirement, 2012). Retirees are those who have retired from their fulltime work. It is a completely changed life. Life after retirement is totally a new one. Retirement is all about starting a new phase of life and it is a main life-changing experience. (Clark, 1960; Cussen, 2018). The process which an individual uses to make a retirement decision may be influenced by a rational allocation of money, time, and effort, as suggested by a utility-maximizing Household Production approach (Brothers, 2013).

Every individuals with some sort retirement education would be aware of the important financial matters that they should look at before they retire. Retirement education is also needed as a guidance to plan financial matters. A survey done in the United States of America among adults showed that American employees depend for their retirement education from their employers, parents and close family/friends (Ramsey, 2016).

Individuals with retirement education realise that a well planned retirement requires individuals to be aware of their retirement needs while working itself (Miller, Madland, \& Weller, 2015). Muller (2002) found that retirement education affects saving behaviour. Individuals need to be aware on how much they need in order to sustain throughout their retirement period. Importance should be given to the savings in advance (U.S. Department of Labor, 2010). Sufficient savings is needed as an aid of support for elderly people upon retirement. 


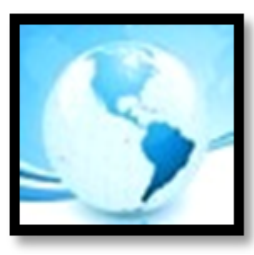

\section{MALAYSIAN ONLINE JOURNAL OF EDUCATIONAL MANAGEMENT (MOJEM)}

In retirement planning, elderly people should be aware of how their savings will be affected by major life events. Elderly people with lesser level of retirement education might have little savings or investments upon retirement will face problems when they come across unexpected costs (Day, 2014). Furthermore, those who want to retire with less financial burden should be able to plan for the future before they retire and this can be accomplished easier by having retirement education. Individuals with lower income need financial planning for retirement more than individuals with higher income (Boisclair, Lusardi \& Michaud, 2014). Financial planning guides individuals to review their financial goals and take necessary steps to update or fulfill the goals (Fontinelle, 2017).

\section{Retirement Planning}

Planning for retirement is an important process to ensure that individuals can have sufficient savings for living a lifestyle that they want upon retirement. It involves an individual's ability to make decision on when to save, how much to save, when to stop working and also when to start using resources that have been saved initially (Topa, Mariano \& Moreno, 2012, p.528). Planning starts from one individual. An individual with sound personal financial plan is able to deal with financial matters wisely (Tan, Hoe \& Hung, 2011).

Financial literacy education is closely related to financial planning (Boisclair, Lusardi \& Michaud, 2014). There is a strong positive relationship between retirement planning and financial relationship (van Rooij, Lusardi \& Alessie, 2012). Arrondel, Debbich and Savignac (2013) explained that individuals with higher levels of financial literacy education have higher chances of planning for their long-term future. A study among Dutch students showed that there is a positive and significant effect of advanced levels of financial literacy education on retirement planning (van Dijk, 2012).

Individuals with lower level of education tend not to plan and save for retirement and individuals also face difficulty to calculate their retirement needs when they cannot perform simple and compound interest calculations (Lusardi \& Mitchell, 2006). Individuals with lower income tend to plan their retirement wisely when they are equipped with financial literacy education. Individuals with higher income tend to be aware with basic features of retirement income system, regardless of their measured level of financial literacy (Boisclair, Lusardi \& Michaud, 2014). Individuals with higher levels of income and education tend to plan for retirement by having a bigger proportion of saving for retirement (Helman, Greenwald \&Associates, Adam, Copeland \& VanDerhei, 2014). Thus, the exposure on financial literacy education affects the retirement planning.

\section{Financial Literacy Education}

The concept of financial literacy education is closely related to retirement planning. Financial literacy education is defined as having pertinent amount of knowledge and skills required to make economic and financial decisions confidently to manage financial resources effectively (Hung et al., 2009, p.10; The Ministry of Education Ontario, 2010). Financial literacy education is also understood as increasing set of financial knowledge, abilities and approaches where the individuals form on throughout life and it is influenced by their mobilization of cognitive and practical skills, attitudes, motivation and values (PISA, 2012). Thus, financial literacy education includes two components; first, acquiring financial knowledge and ability and second the relation between financial knowledge and ability which is build based on individuals' education or experience on finance concepts and products (van Dijk, 2012).

Financial education increases financial literacy of individuals. Financial literacy education is useful in providing sufficient financial knowledge which aid in retirement planning (Ekerdt \& Hackney, 2002; Ntalianis \& Wise, 2011; Yoong, See, \& Baronovich, 2012). In this current era with ultimate financial crisis, it is essential for each and every individual to equip himself or herself with pertinent financial knowledge. Klapper and Panos (2011) carried out a study to figure out the effect of proper financial literacy education on retirement planning in Russia. 
They found that those who are exposed to financial literacy education and equip themselves with pertinent financial literacy education are good in planning for their retirement and investing in private pension funds for their future. Financial literacy education does not start when one starts working; in fact, it should be exposed to the younger generation in schools.

\section{METHODOLOGY}

Exploratory qualitative research method was employed in this study. Qualitative research is done when researchers want to explore a problem to get deeper and richer understanding (Creswell, 2012). Two approaches were used in this study to collect data; interview and document analysis. Interviews are prominent in social sciences and it is always the main method of data collection in a qualitative study (King \& Horrocks, 2010). The main purpose of the interviews were to get valuable opinions from individuals who have experience in dealing with financial planning for retirement on the influence of demographic factors, financial literacy factors, financial attitude factors and financial education factors on financial retirement planning of elderly people in Malaysia.

There are various ways to accumulate information from interviewees, of which the most common interviewing way is one-on-one (Alsshenqeeti, 2014). In this study, one-on-one interviews were conducted with participants to gather pertinent information on the influence of several factors on financial retirement planning. Throughout the interview session, the participants were given the chance to share out their opinions and ideas based on their level of expertise and experiences. The interview was structured into five parts and the parts are shown in Table 1.

Table 1

Interview Structure

\begin{tabular}{|c|c|}
\hline Interview structure & Components \\
\hline $\begin{array}{l}\text { Part I } \\
\text { Introduction }\end{array}$ & $\begin{array}{l}\text { - Brief explanation of the study and interview } \\
\text { - Explain on the rights of participants } \\
\text { - Provide consent form to read and to sign }\end{array}$ \\
\hline $\begin{array}{l}\text { Part II } \\
\text { Personal background }\end{array}$ & $\begin{array}{l}\text { - Identity participants' profession and their job background } \\
\text { - Identify participants' personal experience in dealing with financial situation } \\
\text { - Identify if participants have any financial planning for retirement before they } \\
\text { retire }\end{array}$ \\
\hline $\begin{array}{l}\text { Part III } \\
\text { Financial retirement planning } \\
\text { in Malaysia }\end{array}$ & $\begin{array}{l}\text { - Figure out when they realized the importance of planning their finance for } \\
\text { retirement } \\
\text { - Figure out the effects of mastering financial literacy in planning for retirement }\end{array}$ \\
\hline $\begin{array}{l}\text { Part IV } \\
\text { Determinants of financial } \\
\text { literacy education }\end{array}$ & $\begin{array}{l}\text { - Identify the effects of demographic factors, financial attitude factors, financial } \\
\text { literacy factors and financial education factors on financial retirement planning }\end{array}$ \\
\hline $\begin{array}{l}\text { Part V } \\
\text { Closing }\end{array}$ & $\begin{array}{l}\text { - Clarify any queries } \\
\text { - Recap the whole interview session } \\
\text { - Confirm time for second interview if needed }\end{array}$ \\
\hline
\end{tabular}




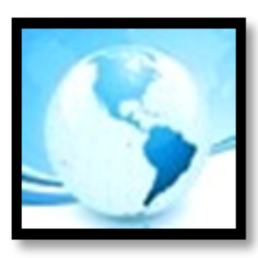

\section{MALAYSIAN ONLINE JOURNAL OF EDUCATIONAL MANAGEMENT (MOJEM)}

Document analysis is also prominent in social sciences. It is often used with other qualitative methods as a mean of triangulation (Bowen, 2009). Document analysis is used to review and evaluate printed and electronic documents to comprehend meaning and gain more understanding (Corbin \& Strauss, 2008). In this study, data was collected through various methods and the findings were collaborated across data sets. Thus, the potential biasness which occurs in this study is reduced.

\section{Sampling}

Interviews were carried out among 10 participants. This sample size is sufficient as Crouch and McKenzie (2006) proposed that less than 20 participants in a qualitative study are sufficient for a researchers to maintain a good relationship and to probe information. In this study, purposeful sampling technique was used to choose 10 participants from Klang Valley. Purposeful sampling is used in qualitative sampling as the researchers intentionally chooses individuals and locations to learn or understand the central phenomenon (Creswell, 2012). Researchers intentionally select participants who are 55 and above and have experience in planning for retirement. Researchers specifically has selected participants and the locations to learn and understand the influence of financial literacy education on retirement planning.

\section{Data Collection Process}

Semi-structured interview consist of a set of key questions and it followed in a more open-ended manner so that the researchers can allow themselves to have an open view about the contours of what they need to find out (Bryman, 2012). Before conducting semi-structured interviews in fieldwork, an interview protocol was developed. Questions were developed based on the research questions, research objectives, and review of the literature.

Participants were contacted for the interviews. The participants are allowed to choose convenient locations for interview sessions (i.e., participant's house, participant's office and restaurant). The interviews were conducted in English. Before interview took place, the participants were briefed verbally about the study, in addition to earlier given information. The participants were informed about their rights as participants and they were asked to read and sign consent form.

The researchers sat facing the participants and the conversations were recorded using voice recorder upon their agreement and later the conversations were transcribed for analysis purpose. After each interview, the recordings are transferred to researchers' personal laptops to ensure that the data is secured and participants' confidentiality is protected.

In this study, the interview sessions ranged between 30 minutes to 80 minutes. Throughout the interviews, researchers attempted to make the participants comfortable when responding to the questions with guiding questions to make sure that the information needed on financial retirement planning is obtained from them.

In addition, during the interviews, researchers also conducted document analysis by looking at the budgets that have been planned by the elderly people in managing their monthly expenditure and saving for their retirement. Researchers requested the participants to show any documents like books, diaries, charts and any written records which are used to write down the monthly budgets or financial planning for retirement.

\section{Data Analysis}

Thematic analysis is used to interpret the data collected in this study according to the thematic analysis method defined by Braun and Clarke (2006) and Merriam (2009). Braun and Clarke (2006) proposed six phases of analysis that will also be used in thematic analysis; familiarization with data, generalization of initial codes, theme formation, reviewing themes, defining and naming themes and report writing. 


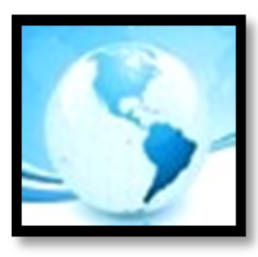

\section{MALAYSIAN ONLINE JOURNAL OF EDUCATIONAL MANAGEMENT (MOJEM)}

The researchers recorded the responses using a voice recorder and notes were taken down. Once the interviews are done, interview transcripts were transcribed in written forms and the researchers familiarise themselves with data by critically analysing the interview transcripts.

During the transcribing process, participants' names are replaced with codes. Coding in interview is vital in ensuring the confidentiality of participants' identities and retrievability of interview data (Protecting Confidentiality \& Anonymity, 2017). In this study, the code for each participant is Participant 1, Participant 2, Participant 3, Participant 4, Participant 5, Participant 6, Participant 7, Participant 8, Participant 9 and Participant 10.

Then, the researchers reads interview notes, observation notes and written documents three times, line-by-line to get the exact meaning and to avoid misunderstanding and misinterpretation. In this first phase, the researchers generate the initial list of ideas for coding.

The process is continued with coding of data into meaningful segments. In this phase, all the collected data is coded accordingly. According to Merriam (2009), 'Open coding' is done at this stage because every bit of data which appears to be valuable is chosen. Then, all the written documents are read once again and the pertinent texts will be chosen and labelled. Meanwhile, the data is categorized into meaningful groups according to interesting aspects in the data items.

Then, all the codes which were generated earlier are reanalysed and the similar codes are combined to develop potential themes. Initially, the researchers develops major themes and then later on the themes are reanalysed and they are merged together under one main theme and others may be divided into sub-themes or new themes are developed. Cresswell (2012) suggested that by reanalysing and merging the themes, the number of themes will be lesser.

The researchers reviews the codes in the theme to ensure the correct coding and coherence among the codes. The researchers also reviews the themes to make sure that the information in each theme is relevant and there is no repetition of discussion in other themes. The researchers names the themes and analyse each theme. The researchers writes up for each theme keeping in mind the research questions. Finally, researchers writes concise and logical themes. The discussion for each theme is supported with the interview excerpts from the interviews.

\section{Reliability and Validity}

In qualitative approach, the concept of trustworthiness is given utmost importance (Merriam, 2009). The semistructured interview protocol was self-administrated by the researchers based from past studies and the questions were validated by two experts from a public university in Kuala Lumpur who have also conducted studies and published papers on ageing. The researchers also asked a language expert who is a university lecturer who has been teaching English language for the past 20 years to validate the interview questions to check the grammar and sentence structure. Hence, the validity and reliability of the interview protocol was assured.

\section{FINDINGS AND DISCUSSION}

Semi-structured interviews and document analysis were conducted to answer the research questions; How financial literacy education can be influential on financial retirement planning of elderly people in Malaysia?? This section presents the findings obtained from the interviews and documentation. 


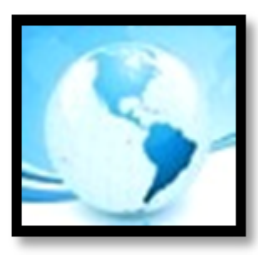

There were six main themes emerged from the data as a result of such analysis with sub-themes; retirement preparedness, financial capability, gender, age and education level, direct and indirect dependency, proper financial skills and informed financial decisions. All the findings gathered during the 10 interview sessions are presented.

\section{Retirement Preparedness}

In response to interview questions, the participants who had experience in dealing with financial planning for retirement elaborated on the importance of financial planning for their retirement. Most of the participants mentioned that they realized the importance of financial planning for retirement earlier since the day they started working and they started saving little by little. Participant 8 informed, "I wanted to plan for my retirement despite of having my monthly commitment like house loan and other necessary expenses but I could not save a lot but, I managed to save a bit" (P8;26-28).

They also tend to invest in mutual funds, share markets and properties. Participant 3 added, "I have planned for my retirement. I took up insurance policy and I invested in unit trust. I also played share market... I will allocate that money as my extra savings" (P3; 24-25). Furthermore, Participant 4 planned his retirement well while he was working. He informed:

"While I was working, my pay was good and I had the chance to start up a printing business as my retirement plan. While working in bank, I took up insurance policy, I invested in unit trust and I also was active in share market. I well-planned everything for my future" (P4; 70-72).

Participant 6 also started own business as a way to plan for future and she also invested in gold and keep aside savings for future use. Participant 6 claimed:

"...The main reason for me to start up my own business was to save up money for me especially when I get older... I invested my money in gold and I allocated money for myself in the bank so that I can use the money in the future" (P6;19-21).

In contrast, despite of having the realization to start planning earlier, certain participants could not follow their financial planning ideas as they faced challenges regardless of their income levels due to various commitments. Participant 5 mentioned:

"I had ideas to plan for my retirement the day I started working; however, I could not follow my ideas as my pay was just sufficient to settle my car loan, house loan, my personal insurance, my utility bills and my daily expenses" (P5; 41-43).

Documentation revealed that, most of the participants filed financial related documents in an organized way. They have separate files for share markets, insurance, unit trust and their pension or Employees Provident Fund (EPF). Most of them believed that financial planning before retirement is essential for the future. Without a proper planning, their retirement will be challenging especially when they come across financial issues after they retire. This is in good agreement with a study done locally by Mohd Fitri Mansor, Chor, Noor Hidayah Abu and Mohd Shahidan Shaari (2015). They discovered that people who do not plan retirement well would need to continue working to maintain their living expenses even upon retirement. A current report by Scotiabank (2017) a Canada multinational bank proved that many people are retiring without giving enough importance to personal financial planning. Thus, a proper financial planning is essential to live a good retirement lifestyle. 


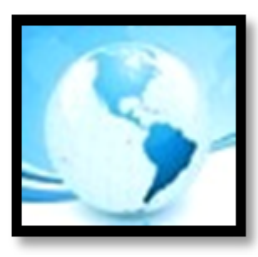

\section{MALAYSIAN ONLINE JOURNAL OF EDUCATIONAL MANAGEMENT (MOJEM)}

Besides that, most of the participants stated that they allocate their salary for their children's education and expenses even though some of them had very little savings for themselves. They mentioned that they can help their children in future upon their retirement with their savings that they allocate for their children. Interestingly even though many faced challenges to save up for themselves for the future every individuals gave utmost priority to plan for the wellbeing of their children in the future. Participant 2 stated that he works extra hours even on public holidays to get extra income and save up for his children. Participant 2 claimed:

"Even though my salary was just nice to maintain a simple life, I gave importance for my children. I will work on public holidays to get double pay so that I can have extra income and that income I will save up for my children... Every month I will keep aside some amount of money for all my children despite of limited amount of money for my own expenses" (P2;76-78;81-83).

Participant 5 said that for his children's education is vital and somehow he will work extra hours to earn extra income to support his children. Participant 5 shared:

"My children's education is important for me. Somehow, I will work extra hours to get more income so that I can support my three children. I also will set aside some allocations for them every month. I also took up insurance for three of them when they were young" (P5;47-50).

Despite of having low salary, the well-being of children becomes the priority. Participant 8 mentioned:

"Even though my salary was very low, I never fail to provide money for my children. For now, I do massage service to get extra income to support both of them who are still in college and I also have a bit of savings for four of my children" (P8; 98-101).

The above findings concur well with what Batie (2017), an expert financial advisor stated. According to her, an important part of financial planning is providing for individual family's financial security. Those individuals who have better income have more confidence in planning for the future of their children. One of the respondents started planning for her children since she started working. She invested in financial matters for her daughters and she is confident that her daughters do not need to worry about financial matters because she has done all the necessary things for her children. She explained:

"I really plan for my children very well since the day I started working. I have joint accounts of public mutual funds with all my three daughters. I also took up medical, education and life insurance policies for my three daughters. Every month I will set aside some amount of money for my retirement and also for my daughters" (P9; 36-40).

Documentation analysis showed that all the participants allocated savings and most of them had insurance policies for their children. They gave priority to their children's future. This finding is consistent with a study done by Helmen, Greenwald \& Associates, Adam, Copeland and VanDerhei (2014). They found that individuals with higher levels of income and education tend to plan for retirement by having a bigger proportion of saving for retirement. Batie (2017) emphasized on taking up insurance coverage and policies is a good choice for an individual and his family for providing financial security. 


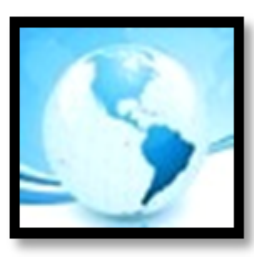

\section{MALAYSIAN ONLINE JOURNAL OF EDUCATIONAL MANAGEMENT (MOJEM)}

\section{Financial Capability}

Financial capability plays a role in money management. Mastering on managing money contributes towards financial planning for retirement. Individuals who have financial literacy education will have the ability to use financial resources well to plan for their retirement. All the participants emphasized on understanding and dealing with money. They said that it is important to have financial literacy education like to have understanding on how money works in real world, how to earn or make money, how to manage money, how to invest money properly and how to even donate money to help others. A participant mentioned:

"There are three main principles when it comes to money; how you earn, how you spend and how you save. In order to master these three principles financial literacy is essential. Everything that you do requires some amount of money and you need to have money in order for you to cope up with current living standards. I always feel happy and satisfied when I donate money to the needy with the extra money that I have accumulated" (P1; 160-163).

In addition, Participant 7 mentioned that it is important to master financial literacy education so that a person can be able to know how to deal with financial situations and below is the excerpt:

"One of the effects of mastering financial literacy is that one can know how to deal with financial situations that will occur often in our daily life. For instance, one should be wise in manaing his salary well every month by spending smartly..." (P7; 66-69).

Another participant mentioned that financial literacy education is also important as individuals need to know how to manage money wisely because depending solely on pension or EPF is risky She said:

"It is definitely risky to purely depend on pension or EPF upon retirement. Every month I had the knowledge to save up at least 30 percent of my income monthly when I was working..." (P3; 55 56).

Thus, in order for an individual to know how to deal with financial situations in their daily life, financial literacy education is essential. Those with financial literacy education will know better on how actually money works and how to deal with it. This reinforces the finding on financial literacy by Hung et al. (2009) and The Ministry of Education Ontario (2010). They found that economic and financial decisions can be made more confidently to manage financial resources effectively with pertinent financial literacy education.

Besides that, participants mentioned that it is important to retire with financial freedom. It means that, before individuals retire they should have settled all their debts and should not have any financial commitments upon retirement. A participant said:

"Before retire all the loans and other debts should be settled. I retired with financial freedom. I had no debts when I retired and I had sufficient savings and that savings can last long. Everyone should retire without debts because after retirement, whatever savings that we have for ourselves can be used for travelling, daily expenses and of course for medical expenses" (P3; 251254).

To add on, another participant said, "...I saved up as much as I can. I cut down my friends and entertainments which are not necessary and now I have settled all my debts before I retire." (P3; 249-251). 


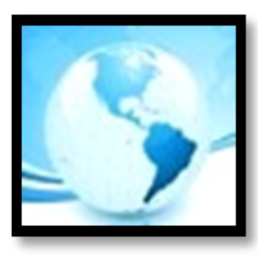

\section{MALAYSIAN ONLINE JOURNAL OF EDUCATIONAL MANAGEMENT (MOJEM)}

Moreover, financial discipline is essential because individuals who have financial discipline will be able to monitor their spending and save up according to their monetary goals. To achieve the goal, they should be willing to obey rules. For individuals to practice financial discipline, they must have financial literacy. A participant explained:

"A person who does not spend unnecessarily has some financial discipline. One should have the discipline to save up money to achieve their monetary goals... Although price of things have risen, if you have financial literacy and financial discipline you can somehow manage your monthly expenses and save up for retirement (P5;184-185;187-189).

Another participant emphasized that in order to have financial discipline, one should have financial literacy to plan their monetary goals. Once he has the goals to achieve, financial discipline comes along.

Documentation indicated that most of the participants had proper recordings on how they manage their monthly budget. Most of them was disciplined enough to record their monthly expenses in notebooks. However, some people did not record their financial related matters in any books or even in their hand phones. Financial literacy education develops an individual's financial discipline to work towards achieving monetary goals. In brief, people need to master financial literacy education in order for them to retire with financial freedom. This finding is consistent with a study done by Cheah et al. (1998) where he found that with financial literacy education people can strategised their financial planning to achieve their financial goals and objectives and this effort results in a better sense of security and ultimate financial freedom. The finding also concurs well with another study which was done locally by Tan, Hoe and Hung (2011). They found that there is an urge for individuals to manage their financial well-being especially in planning their financial goals and objectives as success in financial planning would result in financial freedom (Tan, Hoe \& Hung, 2011).

Furthermore, millennials are also referred as Generation Y. All the participants stated that this generation has a very poor financial planning due to their lifestyle and end up with a lot of debts. Most participants stated that their children who are the millennials do not have the interest to save up for their future as they spend lavishly.

This younger generation also does not have pertinent financial literacy education in order for them to be aware of their financial status and plan for their retirement. A participant said, "Nowadays children like to spend unnecessarily... These children just love to eat outside. Nowadays children they just do not know how to save money for their future." (P2; 120-121;123-125).

Additionally, another participant mentioned that that younger generation tends to spend lavishly by using credit cards. This results in having zero savings and accumulating debts. Therefore, they failed to plan their retirement because when they retire, they retire with debts. He said:

"Younger generation spends lavishly every time they get their salary. The current trend is to use credit cards. They use credit cards for shopping branded and expensive things. Then, they end up buying luxury cars and eat at expensive restaurants. All these result in not having savings at the end of the month and accumulate a lot of debts. They fail to plan for their retirement since the day they start working and when they retire they will have a lot of debts" (P5; 81-85).

Nowadays millennials generation is lack of financial planning because they do not have sufficient knowledge and skills to manage their money in the current challenging economic situation and they end up with disappointment because they have a lot of debts to settle. Thus, financial literacy education is vital for the millennial generation to plan their retirement. 


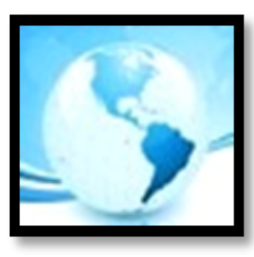

These findings concur well with a survey done report by Wynaendts (2014). The survey report from 15 countries in Americans, Europe and Asia showed that due to financial constraints on households, only 28 per cent of employees have sufficient money to invest for their retirement. This finding also further reinforces the report by Atkinson and Messy (2012). They reported that global monetary crisis associates with higher household well-being and governments all over the world are seeking for opportunity to expose to their people on ways to enhance the level of financial literacy education.

\section{Gender, Age and Education Background}

Demographic factors like gender, age, education background play important roles in financial retirement planning. Generally, based from the opinions from participants, mostly mentioned that women are better in financial planning because they are more family oriented than men. A participant shared: "Women are more family oriented than men. They are more concerned about their family and also the expenses. Even housewives will tend to save up from the money given to them by their husbands or children" (P4; 93-95).

In addition, Participant 1 shared:

"Overall, women are better in saving up money than men. Men tend to have more friends outside and they spend more money for entertainments like eating outside and hanging out with friends at malls... When they get married and start another family or more, they face financial constraints and end up by having poor financial retirement planning. Women on the other hand they are more family-oriented...So, they are better in saving up for the future" $(P 1 ; 283-285 ; 286$ 287).

The findings are consistent with Stewart (2017) who proved that nowadays smart women are more structured and disciplined in managing their financial matters. However, the finding is contrasting with previous studies done by Arrondel et al., (2013), Bucher-Koenen and Lusardi (2011) and Kharchenko (2011) where they proved that males can perform better in financial matters compared to females.

In terms of age, many respondents said that it is always better to have the habit of saving from young age. One respondent in response to the age factor said: "Age is important. Parents should teach their children to save since small age. At young age they should be exposed on ways to save up and spend necessarily" (P5; 167-169). Participant 6 added, "...Age is very important. The importance of financial planning for retirement should be exposed to individuals in younger age itself so that they know how to spend and manage their money wisely" (P6; 140-142).

Additionally, regarding the age another participant claimed:

"Age is definitely essential for planning. Individuals should start thinking about their retirement since young and they should start saving the moment they start working... when I started working I started investing in assets and set aside some amount of money for myself and for my children..." (P1; 332-334).

The findings are in complete agreement with Curtis (2017) who found that young people can start planning since young for their retirement as they have their whole lives ahead and they have ample of time to plan their retirement wisely. This finding is also in consistent with a report by Cassar (2016) who found that financial planning is not only for wealthy and for those who are about to retire. Everyone regardless of wealthy or vice versa should start planning their finance for retirement since young by equipping themselves with proper financial literacy education to succeed in their financial planning for retirement. 
Interestingly, education background does not really affect an individual's financial planning for retirement. One participant mentioned: "Education level is not as important as an individual's attitude. There are educated people who do not know how to plan their finance well and they spend lavishly" (P7; 94-96). To add on, another participant said that it depends on the attitude and the mind set to plan for the future. Regarding attitude, she explained:

"...Education background of an individual does not reflect on his financial planning for retirement; attitude that matters the most. Like my father was not highly educated. In fact he was not a professional but he does small scale business; selling clothes from house to house. However, his financial planning was good..." (P1; 93-95).

Participant 2 shared the same idea; however, he added on that he has seen highly educated individuals have gone bankrupt after they retire. He explained:

"Having the right attitude to save up for future is more important than having higher education level just to plan to save up. Planning comes from individuals. Every individual should know to plan for their retirement based on their work and affordability. Not everyone who is highly educated can save up and plan very well for their retirement (P2; 136-140).

Participant 3 added on that right kind of exposure and influence are more important than education level in financial planning. She said:

"Education level is not the most important factor which affects financial planning. In fact, exposure and influence are more important. When people are exposed to proper ways of saving up and planning for retirement, they can manage their salary and plan for their future well. Influence is also essential. If people are influenced by others who are good in planning for their future, definitely proper financial planning can be done" (P3;79-83).

Document analysis showed that most of the participants did not have certificates for higher level of education attainment but they have planned and organized their financial related matters properly. They mentioned that having the right attitude is more important than having higher level of education when it comes to financial planning. The findings are in strong agreement with a report on adult financial literacy in Australia by ANZ survey (2011). The report depicted that despite of having completed formal post-secondary education; this group of people did not give priority to keep track the finances, or making financial plans for future as they do not have the right financial attitude to do so. However, this finding is contrasting with a study by Lusardi and Mitchell (2011) who found that higher level of educational attainment result in a more positive and greater financial literacy.

\section{Direct and Indirect Dependency}

The attitude towards financial management is affected by factor like having to support direct dependency like spouse, children or grandchildren and indirect dependency like parents, parents-in-law or siblings. Participant 1 said:

"I have 5 children who were depending on me and my husband while they were still schooling and in colleges. I as a mother made sure that all my children get pocket money when they go to school and college. I also had more responsibilities to save up my money because I already set my goal to buy assets for all my children and set aside some allocations for all of them. I also had my niece 


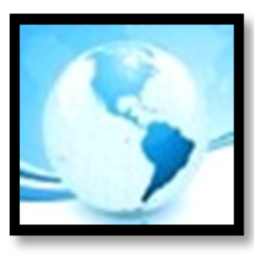

\section{MALAYSIAN ONLINE JOURNAL OF EDUCATIONAL MANAGEMENT (MOJEM)}

to support. Even though she is not my own child, I still set aside some allocations for her. So, most of salary is spent for my children and my niece" (P1;98-101).

Participant 2 mentioned that his salary is just nice for his family; thus, whenever he gets extra bonus or extra income, he will give to his parents. He explained:

"I allocated money for my children's education and also for my wife. If I manage to save extra money, I will give my parents some money. Actually my salary was just nice to save up for my family. Thus, I will give my parents money only when I get bonus or extra income..." (P2; 56-59).

These findings are consistent with Trulia's (2016) report on budgeting. She said that setting monthly budget can be overwhelming initially but it is important to have the financial literacy education and know how much money individuals spend and 50 per cent of individuals income should be budgeted for living expenses and essentials. The finding is also consistent with Cabler (2016) who found that individuals with financial discipline will have a better finance situation like having more savings and build more financial security for them and their family.

Moreover, all the participants did not really know the actual amount that is need for their retirement but all of them are aware of their financial status. According to them, being aware of financial status is essential as it contributes towards planning for their retirement carefully. Their attitude on being confident with their retirement plays a role too to plan for their retirement. Participant 1 said:

"I did not specifically figure out how much is needed for my retirement but I was very alert with my financial status. I often check my bank balance; assets balance payments and other financial matters because I do not like to have debts. So, I will update myself with my financial status every month. I'm very confident with my retirement because I know my savings are sufficient for me. I can be independent until my last breath. I am very confident because I started my retirement planning since the first month I started working" (P1; 211-214).

Participant 2 emphasised on the importance of keeping track with financial status as it plays an important role in planning for retirement. Now, he is very confident with his retirement as he has strong financial background. He explained:

"For me checking on my financial status is important even though I did not specifically figure out on how much saving is needed for my retirement in future. I believed that by checking on my financial status I can do better planning. I am very confident with my retirement now because I have asset, EPF, savings and also insurance which can last for a long time" (P2;180-184).

Participant 3 and Participant 4 said the same thing. They mentioned:

"I did not plan to save any specific amount of money for my retirement but I do aware of financial status. I will keep track with my savings and my extra income that I get every month. I am very confident with my retirement because I believe I have accumulated sufficient money for my retirement" (P3; 119-122).

"I did not know the exact amount that I need to save for my retirement but I was aware of my financial status as I wanted to save up as much as I can for me, my wife and my daughter. I am confident with my retirement as I started my own printing business years ago and the business is good" (P4; 127-130). 


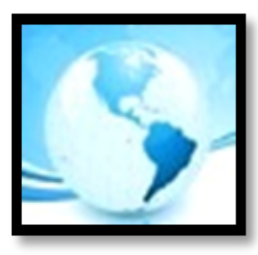

\section{MALAYSIAN ONLINE JOURNAL OF EDUCATIONAL MANAGEMENT (MOJEM)}

Besides, it is also important to keep track with actual spending as it will contribute towards a proper financial planning for retirement. When individuals keep track with their actual spending, they can be more alert with their spending. Regarding the importance of keeping track with actual spending on financial planning for retirement, a participant shared:

"Definitely I keep track with my actual spending as I will need to make sure that I have savings for me and my 5 children at the end of the month. I also keep track of my actual spending so that I do not overspend" (P1; 218-219).

Another participant mentioned that he had a notebook to write down his expenses so that he can easily keep track with his spending. He said, "When I was working, I had my own notebook to write down all my expenses that I spent for. I did that because I wanted to know how I spend my money and I can keep track with my actual spending." Another participant added on. She said:

"I do write down my expenses in a book and I do plan ahead for one year. Like for 2017, I have planned my finance breakdowns until December because I am going for vacations several times in this year. I keep track of my actual spending so that it does not go over the budget that I have planned" (P3; 102-105).

Document analysis revealed that most of the participants record their monthly budgets for themselves and for their family members in notebooks because they said recording the monthly budgets improved their financial planning. A financial planning article by LearnVest (2012) did emphasize on the similar views on monitoring spending. In the article it was stated that keeping track with spending is essential as it can help individuals to save a lot of money and avoid overspending and the money which is not used unnecessarily can be saved for the future.

\section{Proper Financial Skills}

Financial literacy is important because when individuals have proper skills and knowledge on how to plan their finance, they can generate extra income and increase personal savings. In response to the question on generating extra income, Participant 1 shared:

“... Father taught us the skills to save up money and also to generate income from the resources that we have. As I mentioned earlier, by the age of 40 I had 5 houses for my children and that time they were still studying. So, for now I rent out the houses and generate extra income..." (P1; 227-229).

Besides, Participant 3 mentioned that even though she does not have any assets, she has the literacy to save up while working and to generate extra income. She said:

"I do not have any assets but I had the knowledge to save up as much as I can while I was working... I am working as an insurance agent to generate extra income for my own expenses. I need to generate extra income" (P3;113-116).

Participant 4 and 7 admitted that they have the skill and knowledge to save up and invest as now upon retirement they still generate extra income from their investments that they had done ahead of time.

"I rent out 2 of my assets to get extra income especially after my retirement. Now, I am getting extra income from my own business and also from my assets. I am glad that I have the skill and knowledge to save up and invest in assets while I was working because now I am getting extra income from those assets"(P4;41-44). 


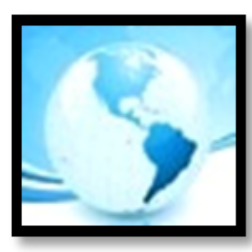

"...Having the skill to invest in assets for getting extra income in future is great. I have another house and I rent it until now. So, now I am getting my pension and my rental money monthly. I learn how to manage the money that I get wisely. I invested in a house while I was working itself so that after retirement I can still generate extra income" (P7;69-73).

In addition, Participant 6 stated that as a single mother even though she is not highly educated, glad that she has the skills and knowledge to generate extra income. She said:

"Even without higher level of education I believe I have the knowledge and skills to manage my money. I continue doing my business and also I also active in organizing trips to local and foreign places to generate extra income. Although I am not highly educated, I have the skills and knowledge on how to manage and save up money for my daughter and for myself. I am a single mother and I would love to be independent" (P6;119-124).

Those individuals who have the skills and knowledge to really plan their finance can surely generate extra income to add on their personal savings for other important expenses that might occur in the future. According to most of the participants, they try minimize their monthly expenses so that they can save up more for themselves. Regarding on how individuals with financial literacy can generate extra income to increase their personal savings, a participant said:

"I not only re-invest my extra income in gold and lands but I saved some of the income in my personal bank. While I was working, I was aware that I will need money in future... I also keep track with my monthly expenses as I wanted to reduce my expenses as much as I can because I had to main aims while I was working; save for retirement and settle debts" (P1;131-132;139141).

Another two participants said that they do monitor their monthly expenses and do monthly budget to ensure proper spending take place and also to increase their personal savings. They shared:

"I do monitor my monthly expenses. I will do a budget to minimize my monthly expenses. By doing budget I can cut down any unnecessary expenses. I will save up as much as I can monthly so that every month my personal saving increases. I think managing the money that you have is a skill that is required by every individual" (P7;117-120).

Documentation showed that most of them have Sales and Purchase Agreement (SPA) for their properties. Participants rent out their houses to get extra income. Others who do not own properties are skilful enough to save up and do business to earn more upon retirement. These findings are consistent with a study done by Lusardi and Mitchell (2013). They found that individuals who have pertinent financial literacy education will have the skills and knowledge would be smart in spending their income accordingly so that they can allocate enough savings for them for retirement. A report by OECD (2013) showed a similar result. It is proven that people need to be financially literate to make proper saving decisions.

\section{Informed Financial Decisions}

Financial education is needed by individuals can learn how to make thoughtful and informed financial decisions by figuring out opinions and ideas on his own, talk to his family, co-workers, friends, consult financial planner or attend financial courses.

According to a participant, financial education is needed to make wise retirement decisions. She planned her retirement on her own and also asked ideas from her family and friends. Sharing ideas among others is a great idea. According to her it is a good idea to attend financial courses since young. She said: 


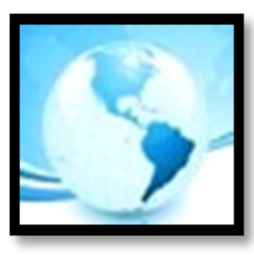

\section{MALAYSIAN ONLINE JOURNAL OF EDUCATIONAL MANAGEMENT (MOJEM)}

"It is very important to have financial education to make proper decisions for retirement. I did plan on my own for my retirement but I also asked opinions from my family and friends. Sharing information and opinions on saving up for retirement is important because we can have more knowledge. Like me, when I was working I had a friend who was a manager in a bank. She knew better on making investments. So, she taught me on how to invest in assets and share markets... My father also taught me on how to save up for my future... It would be a great idea to attend financial courses since young because individuals can get more exposure on how to plan for their retirement and these courses can give awareness to them" (P1;249-252;255-257).

Additionally, another participant said that everyone should have financial education and opinions on financial retirement should be asked from the right person and he also mentioned that it is important to attend financial courses. He shared:

"I believe everyone should have financial education. It is good to ask opinions from the right person. I mixed with those who I see have stable finance background. So, I learnt from them on how to save up and invest for my future. Now, I think it is important to attend financial courses for exposure purpose" (P2; 220-224).

Participant 3 recommended reading a lot of books of financial planning and the habit should start from the individual. She also asked her friend who has experience in financial field on retirement planning. She said:

"I think everyone should read a lot of books on financial planning. The habit of reading book and gaining financial education should start from the individual himself. Besides that, I also got some ideas on finance from my friend who was a senior manager. I also took up several insurance policies because of my friend's influence. There should be financial courses on planning" (P3;150154).

Participant 4 said emphasized that the urge to plan for retirement starts from within. However, ideas from family and friends can be considered. Contradictory to others, he said that he would rather plan on his own by referring to financial planning books or seek ideas from family and friends than attending financial courses which are pricey. He informed:

"Hard work starts from individual himself to plan for retirement. Family and friends can also share their knowledge and experience on how they plan for their retirement. I personally feel that financial courses are not so important and we need to pay extra to attend these courses. I would rather buy books and read on my own or ask for opinions from my family and friends" (P4;154157).

Participant 5 and 8 emphasized that it is good to ask opinions from family and friends who are well verse with finance. They also said that individuals need to attend financial courses while working for a better planning. They informed:

"It is good to share ideas among family and friends who have experience or good background in finance. They can share a lot of information which will be useful for us... Individuals should attend financial courses while working so that they can plan for their retirement ahead of time" (P5;144$145 ; 147-148)$. 


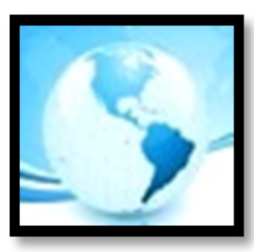

"Gaining knowledge on financial planning from family and friends are important. They might share with us valuable ideas that we ourselves do not know... feel that financial courses are important especially for lower income group of people. They need to get more exposure and financial education from those individuals with good financial backgrounds who conduct financial courses" (P8;104-105;108-110).

Participant 6 emphasized on the importance of financial planning courses and consulting family members. She shared:

"Consulting family members is also important because at times they can also share their opinions...Financial planning courses are very good exposure for people. They can learn on how to plan for retirement earlier if they attend these courses at young age" (P6;126;127;130-132).

Another participant emphasized on discussing with close family and friends and she thinks financial courses are not necessary. She said, "I think we should share our financial constraints with close family and friends because they will share knowledge that they know. I think it is not necessary to attend financial courses because we have to pay extra" (P7; 136-137;140).

In brief, individuals can acquire financial education formally by consulting financial planners or attending financial courses. Individuals can also gain financial education by figuring out opinions and ideas on their own, talk to their family, co-workers, and friends. Sharing information and opinions on saving up for retirement is important because we can have more knowledge on how to plan for retirement. The above findings concur well with findings from several researchers like Ekerdt and Hackney (2002), Ntalianis and Wise (2011), OECD (2009), and Yoong, See and Baronovich (2012). They found that financial education is useful in providing sufficient financial knowledge which aid in saving and investment and retirement planning.

\section{CONCLUSION AND IMPLICATIONS}

In conclusion, this research explored the financial literacy education of elderly people and the influence on financial retirement planning in Malaysia. In this study, interview protocols were used to collect data from 10 elderly people who are aged 55 and above from Klang Valley about their opinions on the financial literacy education and the influence on their financial retirement planning. Along with interview sessions, document analysis was also done. It was found that, participants prioritised financial planning for their retirement in the future and to plan a proper retirement in the future, financial capability in managing money is crucial. It was also found that women tend to be more responsible in financial planning. Participants also shared that since young everyone should be exposed to financial literacy education to plan their retirement.

Higher level of education does not necessarily result in successful retirement planning; hence, the attitude that matters the most. Further, participants shared that by having direct and indirect dependency, they tend to be wiser in managing monthly expenses and develop financial discipline to plan for retirement. Besides that, participants strongly agreed that financial literacy education is needed to accumulate additional income and increase savings. Finally, participants agreed that financial education is needed to make relevant financial decisions by gaining the education on own or from others.

Overall, these findings indicate that financial literacy education does have a strong influence on retirement planning. These findings concur well with Githui and Ngare (2014), confirming that financial literacy education has a strong influence on retirement planning. This current study is the first study to our knowledge to be conducted qualitatively to gather rich and authentic data on the influence of financial literacy education on financial retirement planning. 


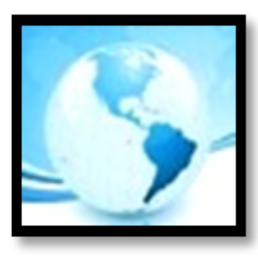

\section{MALAYSIAN ONLINE JOURNAL OF EDUCATIONAL MANAGEMENT (MOJEM)}

The findings of this study provide essential insights on financial literacy education and retirement and this study can be useful not only for Malaysians but also for other countries who give importance to financial retirement planning.

By implication, policy makers ought to imply the results from this study to the working population as they should enhance their financial literacy education especially in managing their monthly expenditure. Policy makers should expose the importance of financial literacy education on retirement planning to every working individual regardless of their Socio Economic Status (SES). It is also essential for policymakers to imply the findings of this current study because there is a rapid increase of ageing population in this world including Malaysia and many of them need to be aware of their financial status and equip themselves with pertinent financial literacy education to plan for their retirement.

Moreover, it is very important to expose the awareness on financial planning for younger generation because saving up and investing for retirement cannot be accomplished in one night. It requires a long term planning and determination. It is effective to spread the awareness on financial planning for retirement to younger generation as they can start saving up consistently at a younger age and when they successfully develop the habit of saving since young, they will plan for retirement well.

These findings should, however be replicated on a larger scale within both urban and rural elderly people. It will be interesting to compare the results gathered from urban and rural settings. Lastly, this study should be conducted with working people who are aged less than 55 years old as a sample to compare the findings with the current study. It will be different to compare the findings as working people who are aged less than 55 years old and working people who are aged more than 55 years old may have different opinions on the financial literacy education and the influence of financial retirement planning.

\section{REFERENCES}

Adult financial literacy in Australia: Full report from the 2011 ANZ survey. (2011). The Social Research Centre. Australia.

Alsshenqeeti, H. (2014). Interviewing as a data collection method: A critical review. English Linguistics Research, 3(1), 39-45. doi: 10.5430/elr.v3n1p39

Arrondel, L., Debbich, M., \& Savignac, F. (2013). Financial literacy and financial planning in France. Numeracy, 6(2), 1-17. doi: http://dx.doi.org/10.5038/1936-4660.6.2.8

Atkinson, A., \& Messy, F.-A. (2012). Measuring financial literacy: Results of the OECD / International Network on Financial Education (INFE) Pilot Study. OECD Working Papers on Finance, Insurance and Private Pensions, 15, $1-73$.

Batie, S. (2017). Ten reasons why financial planning is important. BlueShore Financial. Retrieved from https://www.blueshorefinancial.com/ToolsAdvice/Articles/FinancialPlanning/TenReasonsWhyFinancialPlan ningIsImportant/

Behrman, J.R., Mitchell, O.S., Soo, C., \& Bravo, D. (2010). Financial literacy, schooling, and wealth accumulation. (Working Paper No 16452). Retrieved from http://www.nber.org/papers/w16452.pdf

Bodie, Z., Treussard, J., \& Willen, P. (2007). The theory of life-cycle saving and investing. (FRB of Boston Public Policy Discussion Paper No. 07-3). Retrieved from http://dx.doi.org/10.2139/ssrn.1002388 
Boisclair, D., Lusardi, A.,\& Michaud, P-C.(2014). Financial literacy and retirement planning in Canada. Cirano, 2-29. Retrieved from http://www.cirano.qc.ca/pdf/publication/2014s-35.pdf

Bowen, G.A. (2009). Document analysis as a qualitative research method. Qualitative Research Journal, 9(2), 22-40. Retrieved from https://doi.org/10.3316/QRJ0902027

Braun, V., \& Clarke, V. (2006). Using thematic analysis in psychology. Qualitative Research in Psychology, 3(2), 77101. doi: http://dx.doi.org/10.1191/1478088706qp063oa

Brothers, L.S. (2013). An individual's chosen retirement age: When is the economically feasible retirement age chosen over the anchor provided by known others? Taylor and Francis Online, 7(3), 87-110. doi:10.1080/10920277.2003.10596106

Brugiavini, A., Cavapozzi, D., Padula, M., \& Pettinicchi, Y. (2015). Financial education, literacy and investment attitudes. (NETSPAR Academic Series DP-06/2015-014). Retrieved from http://arno.uvt.nl/show.cgi?fid=137494

Bryman, A. (2012). Social research methods (4 $4^{\text {th }}$ ed). New York: Oxford University Press.

Bucher-Koenen, T. (2011). Financial literacy, riester pensions, and other private old age provision in Germany. (MEA Discussion Paper No. 250-11). Retrieved from http://dx.doi.org/10.2139/ssrn.2014170

Cabler, J. (2016). 9 tips for creating discipline with money. Celebrating Financial Freedom. Retrieved from https://www.cfinancialfreedom.com/9-tips-creating-discipline-with-money/

Cassar, A. (2016, November). Why you should start planning early: What's the value in starting financial planning while you are still young? CEO Magazine. Retrieved from http://www.theceomagazine.com/business/whyyou-should-start-financial-planning-early/

Chaffin, C.R. (2013). The financial planning competency handbook. Canada: John Wiley\& Sons, Inc.

Cheah, E., Devadason, R., Sito, Alex., \& Wong, B.C. (1998). Financial freedom-your guide to lifetime financial planning. KL Mutual Fund Berhad,Kuala Lumpur.

Cheema, A., \& Soman, D. (2006). Malleable mental accounting: The effect of flexibility on the justification of attractive spending and consumption decisions. Journal of Consumer Psychology, 16(1), 33-44. Retrieved from

https://wolfweb.unr.edu/homepage/pingle/Teaching/BADM\%20791/Week\%205\%20Decision\%20Invarian ce/Cheema-Malleable\%20Mental\%20Accounting.pdf

Chowa, G.A.N., Despard, M., \& Osei-Akoto, I. (2012, July). Financial knowledge and attitudes of youth in Ghana. (YouthSave Research Brief No. 12-37). Retrieved from Youth Save Research Brief website: https://csd.wustl.edu/publications/Documents/RB12-37.pdf

Clark, T. (1960). Handbook of social gerontology: Societal aspects of aging. Chicago: University of Chicago Press.

Clark, R.L. (2012). Financial literacy and retirement decisions: The choices facing older workers. CAEL. Retrieved from http://www.cael.org/pdfs/tmt_financial_literacy 
Corbin, J. \& Strauss, A. (2008). Basics of qualitative research: Techniques and procedures for developing grounded theory (3rd ed.). Thousand Oaks, CA: Sage.

Creswell, J.W. (2012). Eductional research: Planning, conducting and evaluating quantitative and qualitative research ( $4^{\text {th }}$ ed.). Boylston Street, Boston: Pearson.

Crouch, M., \& McKenzie, H. (2006). The logic of small samples in interview-based qualitative research. Social Science Information, 45(4), 483-499. doi: 10.1177/0539018406069584

Curtis, G. (2017). Starting early with financial planning. Investopedia. Retrieved from http://www.investopedia.com/articles/younginvestors/07/retirement_planning.asp

Cussen, M.P. (2018). Journey through the 6 stages of retirement. Investopedia. Retrieved from https://www.investopedia.com/articles/retirement/07/sixstages.asp

Day, T. (2014). Understanding the issues facing aging seniors. National Care Planning Council. Retrieved from http://www.longtermcarelink.net/article-2014-6-25.htm

Ekerdt, D. J., \& Hackney, J. (2002). Workers' ignorance of retirement benefits. The Gerontologist, 42, $543-551$. Retrieved from http://dx.doi.org/10.1093/geront/42.4.543

Githui, T., \& Ngare, P. (2014). Financial literacy and retirement planning in the informal sector in Kenya. International Journal of Education and Research, 2(1), 1-16. Retrieved from http://www.ijern.com/journal/January-2014/21.pdf

Fernandes, D., Lynch, J.G., \& Netemeyer,R.G. (2014). Financial literacy, financial education, and downstream financial behaviors. Management Science, 60(8), 1861-1883. Retrieved from http://dx.doi.org/10.1287/mnsc.2013.1849

Fontinelle, A. (2017, September 29). Setting financial goals for your future. Investopedia. Retrieved from https://www.investopedia.com/articles/personal-finance/100516/setting-financial-goals/

Government of Canada. (2005). Why financial capability matters. Retrieved from http://www.fcacacfc.gc.ca/Eng/resources/researchSurveys/Documents/SEDIFCAC_FinCapability-eng.pdf

Heath, C., \& Soll, J.B. (1996, June). Mental budgeting and consumer decisions. The Journal of Consumer Research, 23(1), 40-52. Retrieved from http://bear.warrington.ufl.edu/brenner/mar7588/Papers/heath-solljcr1996.pdf

Helman, R., Greenwald \& Associates, Adam, N., Copeland,C., \& VanDerhei, J. (2014, March). The 2014 retirement confidence survey: Confidence rebounds - for those with retirement plans. (EBRI Issue Brief No. 397). Retrieved from https://www.ebri.org/pdf/briefspdf/ebri_ib_397_mar14.rcs.pdf

Hung, A. A., Parker, A.M., \& Yoong, J.K. (2009, September). Defining and measuring financial literacy. (RAND Working Paper from https://www.rand.org/content/dam/rand/pubs/working_papers/2009/RAND_WR708.pdf 


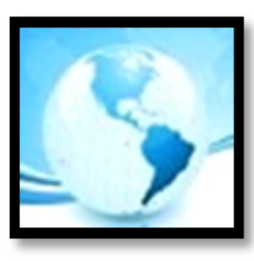

Kast, F., Meier, S., \& Pomeranz, D. (2016, April). Saving more in groups: Field experimental evidence from Chile. (HBS Working Paper No 12-060). Retrieved from http://www.hbs.edu/faculty/Publication\%20Files/12060_8c16f5e7-6fa1-48cc-858d-bba5f12c28ba.pdf

Kharchenko, O. (2011). Financial literacy in Ukraine: Determinants and implications for saving behavior. (Unpublished Master thesis). Kyiv School of Economics, Ukraine.

King, E. (2011). Education is fundamental to development and growth. The World Bank. Retrieved from http://blogs.worldbank.org/education/education-is-fundamental-to-development-and-growth

King, N., \& Horrocks, C. (2010). Interviews in qualitative research. India: SAGE Publication India Pvt Ltd.

Klapper, L., \& Panos, G. A. (2011). Financial literacy and retirement planning: The Russian case. Journal of Pension Economics and Finance, 10(04), 599-618. doi:10.1017/S1474747211000503

Krishna Moorthy, Thamil Durai, Chiau, S.S., Lai, C.L., Ng, Z.K., Wong, C.R., \& Wong, Y.T. (2012). A study on the retirement planning behaviour of working individuals in Malaysia. International Journal of Academic Research in Economics and Management Sciences, 1(2), 54-72. Retrieved from http://www.hrmars.com/admin/pics/696.pdf

LearnVest. (2012). How to avoid the 5 most common financial regrets. Forbes. Retrieved fromhttps://www.forbes.com/sites/learnvest/2012/07/18/how-to-avoid-the-5-most-common-financialregrets/\#6a0ff600e42a

Lusardi, A., \& Mitchell, O. (2006). Financial literacy and planning: Implications for retirement wellbeing. (Working Paper No. WP 2005-108). Retrieved from SSRN website: doi:10.2139/ssrn.881847

Lusardi, A., \& Mitchell, O. (2011). Financial literacy and planning: Implications for retirement wellbeing (Working Paper No. 17078). Retrieved from National Bureau of Economic Research website: http://www.nber.org/papers/w17078.pdf

Lusardi, A., \& Mitchell, O. (2013). The economic importance of financial literacy: Theory and evidence (Working paper 18952). Retrieved from NBER Working Paper Series website: http://www.nber.org/papers/w18952.pdf

Lusardi, A., Michaud, P-C., \& Mitchell, O. (2013). Optimal financial knowledge and wealth inequality. (Working Paper No. 18669). Retrieved from NBER Working Paper Series website: http://www.nber.org/papers/w18669.pdf

Meier, S. \& Sprenger, C.D. (2013). Discounting financial literacy: Time preferences and participation in financial education programs. Journal of Economic Behavior and Organization, 95(2013), 159-174.

Merriam, S.B. (2009). Qualitative research: A guide to design and implementation. San Francisco: John Wiley \&Sons, Inc.

Miller, K., Madland, D., \& Weller, C.E. (2015, January 26). The reality of the retirement crisis. Center for American Progress.

Ministry of Education Ontario. (2010). Report of a sound investment: Financial literacy education in Ontario schools. Retrieved from http://www.edu.gov.on.ca/eng/Financial_Literacy_Eng.pdf 


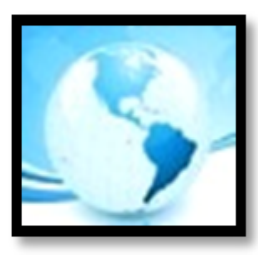

Ministry of Finance Ontario. (2014). Ontario's long-term report on the economy. Retrieved from http://www.fin.gov.on.ca/en/economy/ltr/2014/Itr2014.pdf

Mohd Fitri Mansor., Chor, C.H., Noor Hidayah Abu., \& Mohd Shahidan Shaari. (2015). Demographic factors associated with retirement planning: A study of employees in Malaysian health sectors. Asian Social Science, 11(13), 108-116.

Muller, L.A. (2002). Does retirement education teach people to save pension distributions? Social Security Bulletin, 64(4), 48-65.

Nathan, C.S. (2015, October 7). Having enough for retirement. The Star Online. Retrieved from http://www.thestar.com.my/

Ntalianis, M., \& Wise, V. (2011). Financial structure and policy of Australia's retirement system. Banks and Bank Systems, 6(2), 15-22.

PISA (2012). Financial literacy framework. PISA 2012 assessment and analytical framework. Retrieved from http://www.oecd.org/finance/financialeducation/PISA2012FrameworkLiteracy.pdf

Protecting confidentiality \& anonymity. (2017). Virginia Polytechnic Institute and State University. Retrieved from http://www.irb.vt.edu/pages/confidentiality.htm

Ramsey, D. (2016). Retirement education. Ramsey Solutions. Retrieved from https://www.daveramsey.com/research/retirement-education

Salas, L,M,. (2014). Public vs. private mental accounts: Experimental evidence from savings groups in Colombia. Graduate Center, City University of New York.

Scotiabank. (2017). Importance of planning for retirement. Retrieved from http://www.scotiabank.com/ca/en/0,,3145,00.html

Society of Actuaries. (2012). Key findings and issues: Working in retirement. 2011 risks and process of retirement survey report.

Stewart, B. (2017). How smart women are managing their money in 2017: Rich thinking. Retrieved from http://barbarastewart.ca/RT_WP7-R2017.pdf

Suhaimi Abd Samad \& Norma Mansor. (2013). Population ageing and social protection in Malaysia. Malaysian Journal of Economic Studies, 50(2), 139-156. Retrieved from https://mjes.um.edu.my/index.php/MJES/article/view/2873/1047

Supriya Surendran. (2016). Malaysian investors most indebted in Asia-Manulife survey. Theedgemarket.com. Retrieved from http://www.theedgemarkets.com/article/malaysian-investors-most-indebted-asiamanulife-survey

Tan, H.B., Hoe, S.Y., \& Hung, W.T.(2011). Financial literacy and personal financial planning in Klang Valley, Malaysia. Int. Journal of Economics and Management, 5(1), 149-168. Retrieved from http://econ.upm.edu.my/ijem/vol5no1/bab08.pdf 


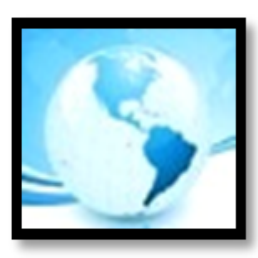

\section{MALAYSIAN ONLINE JOURNAL OF EDUCATIONAL MANAGEMENT (MOJEM)}

Thaler, R.H. (1999). Mental accounting matters. Journal of Behavioral Decision Making, 12, 183-206. Retrieved from http://citeseerx.ist.psu.edu/viewdoc/download?doi=10.1.1.174.2961\&rep=rep1\&type=pdf

The Organization for Economic Cooperation and Development (OECD). (2009). Financial education and the crisis: Policy paper and guidance. Retrieved from http://www.oecd.org/finance/financial-education/50264221.pdf

The Organization for Economic Cooperation and Development (OECD). (2011). Trends in retirement and in working at older ages. Government at a glance. Retrieved from http://dx.doi.org/10.1787/pension_glance-2011-en

The Organization for Economic Cooperation and Development (OECD). (2013). Pensions at a glance 2013: OECD and G20 indicators. doi: 10.1787/19991363

Topa, G., Moriano, J.A., \& Moreno, A. (2012). Psychosocial determinants of financial planning for retirement among immigrants in Europe. Journal of Economic Psychology, 33(2012), 527-537.

Trulia. (2016). New to budgeting? Why you should try the 50-20-30 rule. Forbes. Retrieved from https://www.forbes.com/sites/trulia/2016/07/11/new-to-budgeting-why-you-should-try-the-50-20-30rule/\#2094681d32e9

U.S. Department of Labor. (2010). Savings fitness: A guide to your money and your financial future. Employee $\begin{array}{llll}\text { benefits } \quad \text { security } & \text { administration } & \text { Retrieved }\end{array}$ http://www.dol.gov/ebsa/publications/savingsfitness.html

Van Dijk, N. (2012). The effect of financial literacy on retirement planning among Dutch students. (Unpublished Master thesis). University of Amsterdam, Amsterdam.

Van Rooij, M.C.J., Lusardi, A., \& Alessie, R.J.M. (2012). Financial literacy, retirement planning and household wealth. The Economic Journal, 122(560), 449-478. doi: 10.1111/j.1468-0297.2012.02501.x

Wynaendts, A. (2014). The changing face of retirement: The Aegon retirement readiness survey 2014. Retrieved from https://www.aegon.com/siteassets/research/2014-retirement-survey/aegon-retirement-survey2014.pdf

Yoong, F.J., See, B. L., \& Baronovich, D.-L. (2012). Financial Literacy Key to Retirement Planning in Malaysia. Journal of Management and Sustainability, 2(1), 75-86. doi:10.5539/jms.v2n1p75 